\title{
EVALUASI STRUKTUR GEDUNG DENGAN SISTEM RANGKA BETON PEMIKUL MOMEN KHUSUS BERBASIS KINERJA
}

\author{
Richard Geraldi $^{1}$, Daniel Christianto ${ }^{2}$ dan Hadi Pranata ${ }^{3}$ \\ ${ }^{1}$ Program Studi Sarjana Teknik Sipil, Universitas Tarumanagara, Jl. Letjen S. Parman No.1 Jakarta \\ Email: ricadgeraldi@gmail.com \\ ${ }^{2}$ Program Studi Sarjana Teknik Sipil, Universitas Tarumanagara, Jl. Letjen S. Parman No.1 Jakarta \\ Email:daniel@untar.ac.id \\ ${ }^{3}$ Program Studi Sarjana Teknik Sipil, Universitas Tarumanagara, Jl. Letjen S. Parman No.1 Jakarta \\ Email: hp.rematha@gmail.com
}

\begin{abstract}
ABSTRAK
Indonesia merupakan salah satu wilayah yang memiliki resiko tinggi terhadap terjadinya gempa bumi. Gempa bumi yang terjadi dapat menimbulkan kerugian yang sangat besar, salah satunya adalah korban jiwa dalam jumlah yang besar. Oleh karena itu, diperlukannya suatu bangunan tahan gempa untuk mengurangi kerugian yang dapat terjadi. Perencanaan gempa yang umum digunakan saat ini adalah perencanaan berbasis gaya, dimana respons struktur terhadap gempa dianalisis pada kondisi elastis. Namun, pada kondisi sebenarnya struktur akan mengalami kondisi inelastis ketika terkena gempa. Untuk mengatasi kekurangan itu, berkembanglah perencanaan berbasis perpindahan dimana gaya gempa desain ditentukan berdasarkan perpindahan maksimum yang diizinkan pada kondisi inelastik dan kinerja minimum yang diharapkan dari suatu gedung berdasarkan fungsinya. Peraturan gempa yang ada saat ini menggunakan perencanaan berbasis gaya sehingga diperlukan evaluasi terhadap bangunan untuk memastikan kinerjanya pada tingkat minimum yang diizinkan. Untuk menganalisis bangunan pada kondisi inelastik, digunakan analisis pushover dan Direct Displacement Based Design yang diharapkan dapat menggambarkan kondisi bangunan yang sebenarnya. Tingkat kinerja dari struktur bangunan yang didesain berdasarkan SNI 1726:2012 dievaluasi dengan menggunakan metode kapasitas spektrum yang diatur dalam ATC-40 dan FEMA 440 serta metode koefisien perpindahan yang diatur dalam FEMA 356 dan FEMA 440. Hasil yang diperoleh menggambarkan bahwa bangunan yang didesain dengan SNI 1726:2012 ini memiliki tinkat kinerja Immediate Occupancy yang berarti bahwa bangunan ini memenuhi tingkat kinerja minimum yang ditetapkan, yaitu life safety.
\end{abstract}

Kata kunci: desain berbasis perpindahan, analisis pushover, tingkat kinerja, metode spektrum kapasitas, metode koefisien perpindahan.

\section{PENDAHULUAN}

Indonesia merupakan salah satu negara yang memiliki resiko tinggi mengalami gempa bumi. Hal ini disebabkan karena letak geografis Indonesia yang berada pada pertemuan 3 buah lempeng tektonik, yaitu lempeng Eurasia, lempeng Pasifik dan lempeng Indo-Australia yang selalu bergerak satu sama lain. Selain itu, Indonesia juga dilewati oleh jalur Cincin Api Pasifik (Ring of Fire) yang merupakan kawasan yang dipenuhi gunung berapi.

Berbagai kerugian dengan tingkatan yang berbeda-beda dapat ditimbulkan akibat terjadinya gempa bumi, seperti kerusakan pada bangunan yang dapat mengakibatkan korban jiwa dalam jumlah yang cukup besar. Untuk mengurangi jumlah korban jiwa, maka sangatlah penting suatu bangunan direncanakan agar tahan terhadap gempa, minimal struktur tersebut memenuhi suatu kinerja minimum, yaitu life safety dimana bangunan tersebut diperbolehkan mengalami kerusakan tetapi tidak mengalami keruntuhan.

Saat ini sedang berkembang suatu konsep perencanaan gempa berbasis kinerja yang dikenal dengan Performance Based Design untuk mengetahui performa dari bangunan. Konsep ini merupakan kombinasi dari aspek tahanan dan aspek layan. Dalam perencanaan ini, kinerja struktur gedung terhadap gempa ketika kondisi inelastis dianalisis dengan metode Direct Displacement Based Design dimana gaya gempa yang digunakan dalam mendesain struktur ditentukan berdasarkan target perpindahan serta kinerja batas yang telah direncanakan. Pola keruntuhan dalam perencanaan ini dinyatakan dalam bentuk kurva kapasitas yang dianalisis menggunakan analisis statik nonlinier atau analisis Pushover. 
Analisis Pushover menghasilkan kurva yang menggambarkan hubungan antara base shear dan roof displacement yang disebut sebagai kurva kapasitas. Kurva kapasitas tersebut memperlihatkan perilaku struktur gedung saat kondisi elastis, plastis, sampai terjadinya keruntuhan pada elemen struktur. Berdasarkan kurva kapasitas yang diperoleh, kinerja suatu struktur bangunan dapat diketahui dengan metode spektrum kapasitas berdasarkan peraturan ATC-40 dan FEMA 440, dan metode koefisien perpindahan berdasarkan peraturan FEMA 356 dan FEMA 440.

Seiring dengan berkembangnya ilmu pengetahuan dan tuntutan akan ketahanan bangunan terhadap gempa, maka peraturan yang berlaku juga akan terus dikembangkan. Bagi bangunan-bangunan eksisting yang sudah dibangun dan direncanakan dengan peraturan lama, tidaklah mungkin untuk membongkar dan mendirikannya kembali berdasarkan peraturan baru karena memerlukan waktu dan biaya yang sangat besar. Salah satu cara yang mungkin dapat dilakukan adalah dengan mengevaluasi gedung eksisting tersebut untuk meengetahui kesesuaian kinerja bangunan terhadap kinerja yang diharapkan dalam peraturan baru. Dengan adanya perencanaan gempa berbasis kinerja, maka kinerja bangunan terhadap gempa dapat dinyatakan secara jelas sehingga taraf kerusakan yang diizinkan atau level kinerja dari bangunan terhadap gempa rencana yang terjadi dapat diketahui.

\section{Bangunan tahan gempa}

Suatu bangunan dikatakan sebagai bangunan tahan gempa apabila struktur yang direncanakan tersebut memiliki kekakuan lateral yang mencukupi untuk mempertahankan kondisi elastiknya ketika menerima beban gempa kecil. Selain itu, struktur tersebut harus dapat menahan beban gempa menengah tanpa terjadi kerusakan pada elemen struktural, namun diperbolehkan terjadi pada elemen nonstruktural, dan pada gempa kuat elemen struktural dan nonstruktural diperbolehkan mengalami kerusakan parah namun struktur tidak boleh runtuh.

\section{Desain berbasis gaya}

Beban gempa desain didesain pada saat respons elastik, namun dalam keadaan sebenarnya struktur mampu untuk menyerap energi gempa dalam bentuk deformasi inelastik dengan mekanisme terjadinya sendi plastis pada elemen struktur sehingga dalam desain berbasis gaya diberikan faktor modifikasi respons, $R$, yaitu perbandingan nilai gaya pada saat respons elastik dengan gaya desain.

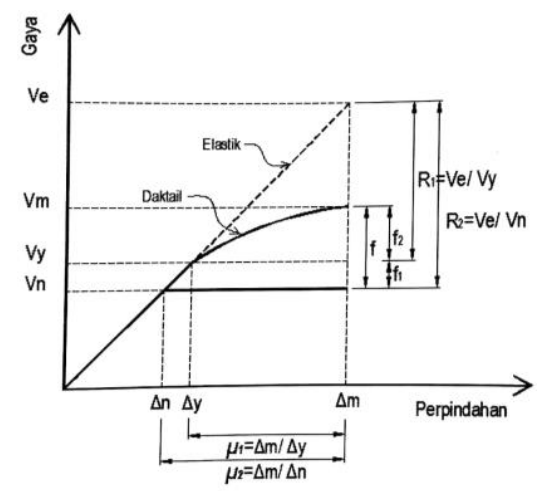

Gambar 1. Kurva Gaya dan Perpindahan pada Respons Elastik dan Inelastik akibat Gempa

(Tavio dan Usman Wijaya, $2018: 52$ )

Pada Gambar 1 terlihat bahwa dalam desain berbasis gaya, gaya geser desain yang digunakan adalah gaya geser nominal, $V n$, yang nilainya diambil dari gaya geser elastik, $V e$, dibagi dengan faktor modifikasi respons, $R$. Nilai $R$ ditentukan berdasarkan kemampuan sistem struktur untuk berdeformasi inelastik atau menyerap energi gempa.

\section{Desain berbasis perpindahan}

Metode desain berbasis perpindahan muncul untuk mengatasi kelemahan-kelemahan yang terdapat dalam metode desain berbasis gaya. Metode ini menekankan pada nilai perpindahan sebagai acuan untuk menentukan kekuatan yang diperlukan bangunan sebagai gempa desain. Pada metode desain berbasis perpindahan, struktur akan didesain sebagai model berderajat kebebasan satu $(S D O F)$ dengan representasi dari kinerja pada respons perpindahan puncak, bukan oleh karakteristik elastik awal. Secara umum konsep desain berbasis perpindahan ini digambarkan pada Gambar 2. 


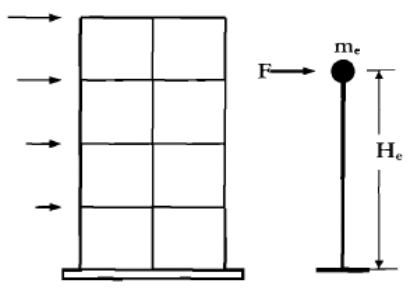

(a) SDOF Simulation

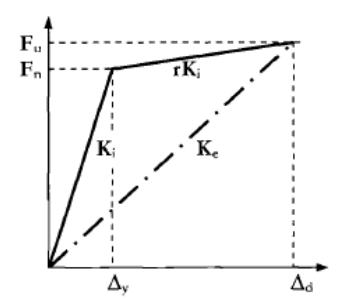

(b) Effective Stiffness $K_{c}$

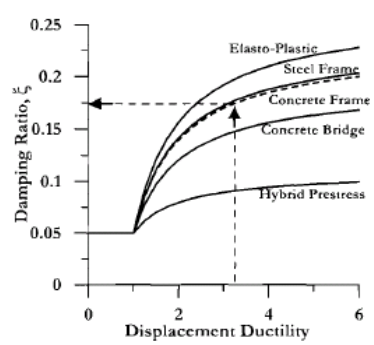

(c) Equivalent damping vs. ductility

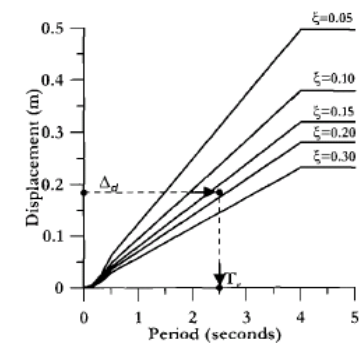

(d) Design Displacement Spectra

Gambar 2. Konsep Desain Berbasis Perpindahan (Priestley, 2007 : 64)

Sistem berderajat kebebasan banyak $(M D O F)$ dimodelkan menjadi bentuk dengan sistem berderajat kebebasan tunggal $(S D O F)$. Nilai gaya geser pada keadaan inelastik maksimum dapat dihitung dengan mengetahui karakteristik kekakuan efektif struktur hasil idealisasi respons histerestik inelastis struktur pada sistem berderajat kebebasan tunggal (SDOF) dengan representasi kinerja pada respons perpindahan puncak.

Respons spektrum gempa desain seperti yang tercantum dalam berbagai peraturan menggambarkan respons gempa elastik dengan redaman 5\%. Dalam desain berbasis perpindahan, desain respons tidak lagi dalam keadaan elastis akan tetapi dengan karakteristik redaman inelastis dari struktur sehingga respons gempa elastis akan dikonversi menjadi redaman inelastis dari struktur yang didesain. Selanjutnya, nilai respons gempa saat redaman inelastis struktur akan diubah dalam format spektra perpindahan untuk mengetahui nilai periode efektif dari sistem berderajat kebebasan tunggal $(S D O F)$, saat respons perpindahan puncak dengan redaman inelastis dari sistem. Nilai periode efektif sistem ini akan sangat mempengaruhi besarnya nilai kekakuan efektif sistem sehingga nilai gaya geser dasar pada saat keadaan inelastis dapat ditentukan.

\section{Analisis pushover}

Analisis statik nonlinier pushover atau analisis beban dorong statik merupakan prosedur analisis yang digunakan untuk mengetahui perilaku keruntuhan suatu bangunan terhadap gempa. Analisis dilakukan dengan memberikan suatu pola beban lateral statik pada struktur, yang kemudian secara bertahap ditingkatkan sampai target perpindahan lateral dari suatu titik acuan tercapai atau struktur mencapai keruntuhan. Biasanya titik acuan tersebut merupakan titik pusat massa pada atap bangunan. Analisis pushover menghasilkan kurva kapasitas yang menggambarkan hubungan antara gaya geser dasar $(V)$ dan perpindahan titik acuan pada atap $\left(\Delta_{\text {roof }}\right)$. Kurva kapasitas akan memperlihatkan kondisi linier sebelum mencapai kondisi leleh dan selanjutnya berperilaku nonlinier. Kurva pushover dipengaruhi oleh pola distribusi gaya lateral yang digunakan sebagai beban dorong. Berdasarkan kurva kapasitas yang diperoleh dapat diperkirakan besarnya gaya maksimum dan deformasi yang terjadi.

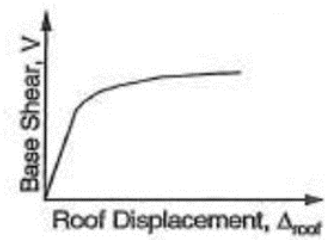

Gambar 3. Kurva Kapasitas Pushover

\section{Kinerja struktur metode $A T C-40$}

Berdasarkan ATC-40, kinerja struktur ditentukan dengan menggunakan metode spektrum kapasitas, yaitu dengan memplotkan demand respons spektrum dan kurva kapasitas dalam satu format antara spektral percepatan dan spektral perpindahan atau disebut sebagai format Acceleration-Displacement Response Spectra (ADRS). Pada Gambar 4, tingkat kinerja dalam $A T C-40$ digambarkan dalam kurva kapasitas. Tingkat kinerja tersebut dibagi menjadi: Immediate Occupancy (IO), Damage Control (DC), Life Safety (LS), Limited Safet, Structural Stability (SS), Not Considered. 


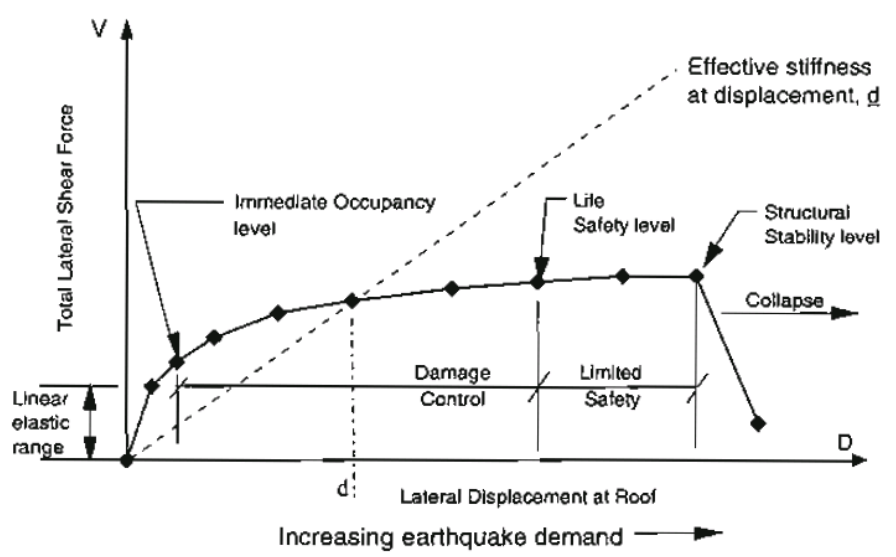

Gambar 4. Tipikal Kurva Kapasitas pada Berbagai Tingkat Kinerja Struktur (ATC-40, 1996 : 6-6)

Deformasi lateral pada saat performance point harus dicek terhadap deformasi limit yang ditetapkan dalam ATC-40, 1996 Bab 11.3.3. Batas deformasi pada berbagai tingkat kinerja dilihat pada Tabel 1 berikut.

Tabel 1. Batasan Simpangan pada Tingkat Kinerja Struktur (ATC-40, 1996 : 11-4)

\begin{tabular}{ccccc}
\hline $\begin{array}{c}\text { Batas Simpangan } \\
\text { Antar Tingkat }\end{array}$ & Immediate Occupancy & Damage Control & Life Safety & $\begin{array}{c}\text { Structural } \\
\text { Stability }\end{array}$ \\
\cline { 2 - 5 } & 0,01 & $0,01-0,02$ & 0,02 & $0,33 V_{i} / P_{i}$ \\
\hline $\begin{array}{c}\text { Simpangan Total } \\
\text { Maksimum }\end{array}$ & 0,005 & $0,005-0,015$ & Tidak ada Batasan & Tidak ada Batasan \\
\hline $\begin{array}{c}\text { Simpangan Inelastis } \\
\text { Maksimum }\end{array}$ & &
\end{tabular}

\section{Kinerja struktur metode FEMA 356 dan FEMA 440}

Berdasarkan FEMA 356, kinerja struktur bangunan saat terjadi gempa dibagi menjadi beberapa kategori yang dapat dilihat pada Gambar 5. Tingkat kinerja FEMA ini secara garis besar adalah sama dengan tingkat kinerja dalam $A T C$ 40 .

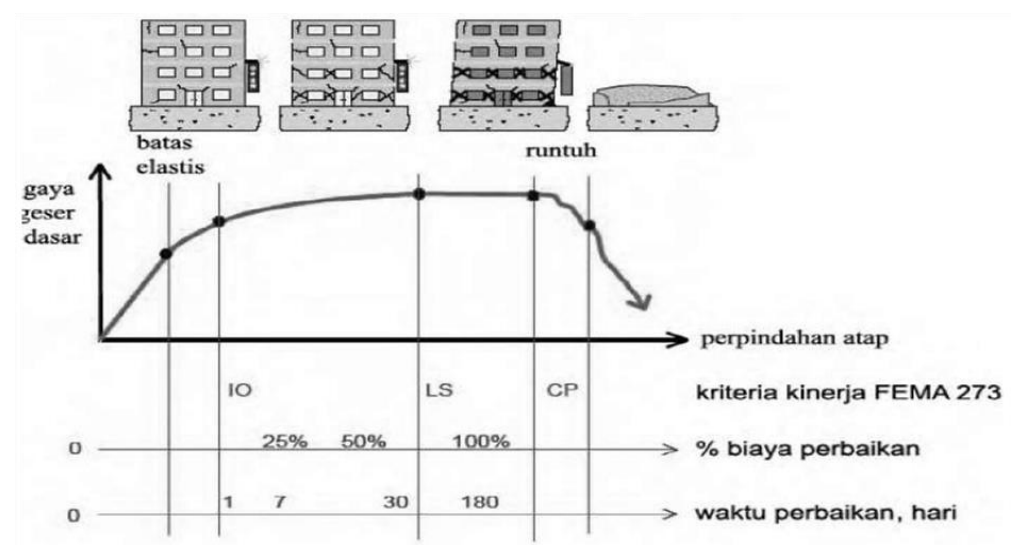

Gambar 5. Tingkat Kinerja Struktur (Tavio dan Usman Wijaya, 2018 : 44)

Metode koefisien perpindahan dalam FEMA 356 adalah suatu pendekatan yang menyediakan perhitungan numerik langsung dari perpindahan global maksimum pada struktur. Penyelesaian dilakukan dengan memodifikasi respons elastis dari sistem SDOF ekuivalen dengan faktor koefisien $C_{0}, C_{1}, C_{2}$, dan $C_{3}$ sehingga diperoleh perpindahan global maksimum (elastis dan inelastis) yang disebut target perpindahan $\left(\delta_{T}\right)$. Pada $F E M A 440$, metode koefisien perpindahan diperbaiki atau dimodifikasi dalam menentukan parameter $C_{1}$ dan $C_{2}$.

\section{METODOLOGI PENELITIAN}

Pada penelitian ini, pemodelan dan analisis dilakukan dengan menggunakan bantuan program ETABS. Struktur dimodelkan sebagai struktur 3 dimensi dengan sistem struktur berupa balok dan kolom. Perencanaan awal struktur direncanakan berdasarkan SNI 1726:2012 yang kemudian dievaluasi dengan menggunakan analisis statik nonlinier. 


\section{Deskripsi umum struktur}

Struktur gedung yang dimodelkan merupakan struktur gedung beton bertulang dengan sistem penahan gempa berupa sistem rangka pemikul momen khusus yang terdiri dari balok dan kolom. Jumlah tingkat bangunan yang digunakan berjumlah 15 tingkat dengan tinggi tingkat pertama yaitu 4,5 meter dan 4,8 meter untuk tingkat lainnya. Denah bangunan berbentuk persegi dengan ukuran 41,4 x 41,4 meter. Data gedung yang digunakan dapat dilihat pada Tabel 2 .

Tabel 2. Data Model Struktur Gedung

\begin{tabular}{cc}
\hline Lokasi & Jakarta Pusat \\
\hline Fungsi & Kantor \\
\hline Ukuran & $41,4 \times 41,4 \mathrm{~m}$ \\
\hline Jumlah lantai & 15 tingkat \\
\hline Tinggi bangunan & $71,7 \mathrm{~m}$ \\
\hline Tinggi lantai 1 & $4,5 \mathrm{~m}$ \\
\hline Tinggi lantai tipikal & $4,8 \mathrm{~m}$ \\
\hline Sistem struktur & $\begin{array}{c}\text { Rangka beton pemikul } \\
\text { momen khusus }\end{array}$ \\
\hline
\end{tabular}
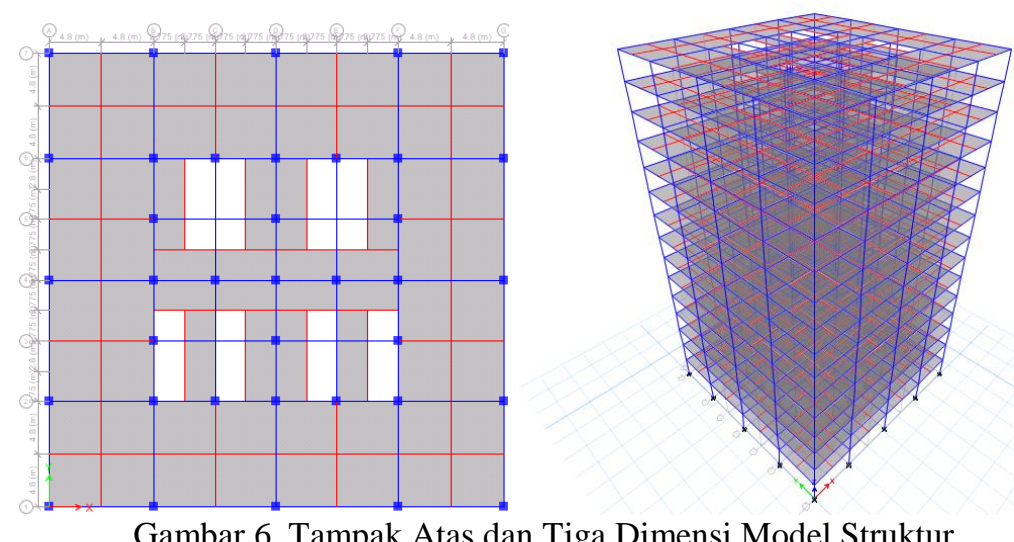

Gambar 6. Tampak Atas dan Tiga Dimensi Model Struktur

\section{Prosedur analisis}

Dalam penelitian ini, gaya gempa desain dihitung berdasarkan SNI 1726:2012 dengan membandingkan metode gaya lateral ekivalen yang diperoleh berdasarkan perhitungan dan metode spektrum respons ragam yang diperoleh dengan bantuan program ETABS. Berdasarkan hasil perbandingan tersebut, akan diperoleh gaya gempa desain untuk masing-masing tingkat yang kemudian dimasukan ke dalam program ETABS.

Setelah itu dilakukan analisis gaya dalam dengan bantuan program ETABS berdasarkan kombinasi pembebanan yang ada sehingga diperoleh gaya momen, lintang dan normal masing-masing elemen yang kemudian digunakan untuk mendesain penulangan. Hasil penulangan tersebut dimasukan kembali ke dalam program ETABS untuk selanjutnya dilakukan analisis pushover.

Berdasarkan hasil analisis pushover akan terlihat pola keruntuhan dari model struktur. Selain itu dihasilkan juga kurva pushover yang menggambarkan hubungan antara gaya geser dasar dan perpindahan atap. Kurva ini yang kemudian akan digunakan untuk mengevaluasi kinerja dari struktur dengan menggunakan metode spektrum kapasitas berdasarkan ATC-40 dan FEMA 440, dan metode koefisien perpindahan berdasarkan FEMA 356 dan FEMA 440.

Selanjutnya gaya geser dasar yang diperoleh berdasarkan SNI 1726:2012 akan dibandingkan dengan gaya geser dasar yang dihitung dengan menggunakan metode Direct Displacement Based Design dengan kinerja struktur yang direncanakan berada pada tingkat life safety (tingkat kinerja minimum). Prosedur dalam penelitian ini digambarkan dalam bentuk diagram alir yang dapat dilihat pada Gambar 7. 


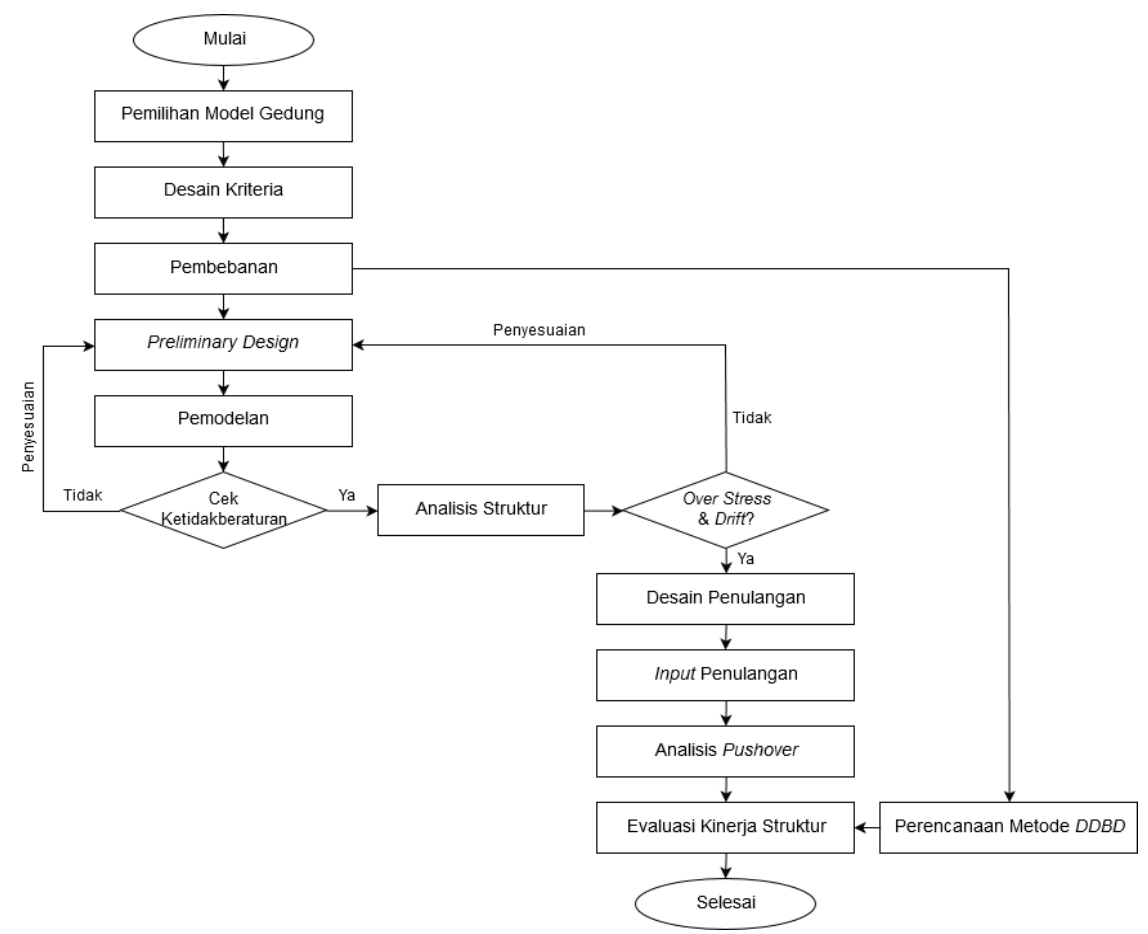

Gambar 7. Diagram Alir Proses Pelaksanaan Penelitian

\section{ANALISIS DAN PEMBAHASAN}

\section{Analisis gempa rencana}

Perhitungan gaya gempa rencana dilakukan dengan membandingkan hasil dari metode gaya lateral ekivalen dan metode respons spectrum ragam. Gaya gempa rencana merupakan gaya gempa terbesar dari gaya gempa statik dan gaya gempa dinamik. Hasil perhitungan gaya gempa rencana dapat dilihat pada Tabel 3.

Tabel 3. Gaya Gempa Rencana untuk Arah X dan Arah Y

\begin{tabular}{|c|c|c|c|c|c|c|c|c|c|c|}
\hline \multirow[b]{2}{*}{ Tingkat } & \multicolumn{2}{|c|}{ Statik } & \multicolumn{2}{|c|}{ Dinamik } & \multicolumn{2}{|c|}{$85 \%$ x Statik } & \multicolumn{2}{|c|}{ SF x Dinamik } & \multicolumn{2}{|c|}{ Rencana } \\
\hline & $\begin{array}{c}\text { FX } \\
(\mathrm{kN})\end{array}$ & $\begin{array}{c}\text { Fy } \\
(\mathrm{kN})\end{array}$ & $\begin{array}{c}\text { FX } \\
(\mathrm{kN})\end{array}$ & $\begin{array}{c}\text { Fy } \\
(\mathrm{kN})\end{array}$ & $\begin{array}{c}\text { FX } \\
(\mathrm{kN})\end{array}$ & $\begin{array}{c}\text { Fy } \\
(\mathrm{kN})\end{array}$ & $\begin{array}{c}\text { Fx } \\
(\mathrm{kN})\end{array}$ & $\begin{array}{c}\text { Fy } \\
(\mathrm{kN})\end{array}$ & $\begin{array}{c}\mathrm{Fx} \\
(\mathrm{kN})\end{array}$ & $\begin{array}{c}\text { Fy } \\
(\mathrm{kN})\end{array}$ \\
\hline 15 & 1330,9 & 1331,3 & 941,5 & 941,7 & 1131,3 & 1131,6 & 974,4 & 974,5 & 1131,3 & 1131,6 \\
\hline 14 & 1544,4 & 1544,9 & 1087,3 & 1087,4 & 1312,7 & 1313,2 & 1125,2 & 1125,3 & 1312,7 & 1313,2 \\
\hline 13 & 1347,6 & 1348,1 & 909,6 & 909,6 & 1145,4 & 1145,9 & 941,3 & 941,3 & 1145,4 & 1145,9 \\
\hline 12 & 1163,0 & 1163,5 & 764,8 & 764,8 & 988,6 & 989,0 & 791,5 & 791,5 & 988,6 & 989,0 \\
\hline 11 & 990,9 & 991,3 & 646,5 & 646,5 & 842,2 & 842,6 & 669,1 & 669,1 & 842,2 & 842,6 \\
\hline 10 & 831,3 & 831,7 & 547,1 & 547,1 & 706,6 & 707,0 & 566,2 & 566,2 & 706,6 & 707,0 \\
\hline 9 & 684,6 & 685,0 & 480,3 & 480,3 & 581,9 & 582,2 & 497,1 & 497,1 & 581,9 & 582,2 \\
\hline 8 & 550,9 & 551,2 & 437,8 & 437,8 & 468,3 & 468,6 & 453,1 & 453,1 & 468,3 & 468,6 \\
\hline 7 & 430,5 & 430,8 & 408,6 & 408,6 & 365,9 & 366,2 & 422,9 & 422,9 & 422,9 & 422,9 \\
\hline 6 & 323,8 & 324,0 & 393,5 & 393,5 & 275,2 & 275,4 & 407,2 & 407,3 & 407,2 & 407,3 \\
\hline 5 & 234,4 & 234,6 & 381,5 & 381,6 & 199,3 & 199,5 & 394,8 & 394,9 & 394,8 & 394,9 \\
\hline 4 & 157,7 & 157,9 & 360,9 & 360,9 & 134,1 & 134,2 & 373,5 & 373,5 & 373,5 & 373,5 \\
\hline 3 & 92,2 & 92,3 & 314,3 & 314,3 & 78,4 & 78,5 & 325,3 & 325,3 & 325,3 & 325,3 \\
\hline 2 & 43,0 & 43,1 & 229,4 & 229,4 & 36,6 & 36,6 & 237,4 & 237,4 & 237,4 & 237,4 \\
\hline 1 & 11,3 & 11,4 & 94,0 & 94,0 & 9,6 & 9,7 & 97,3 & 97,3 & 97,3 & 97,3 \\
\hline
\end{tabular}

Gaya gempa desain ini yang akan digunakan untuk kombinasi pembebanan dalam program ETABS, kemudian dilakukan desain penulangan untuk masing-masing elemen struktur seperti balok dan kolom. Setelah itu hasil penulangan yang diperoleh dimasukan ke dalam program untuk dilakukan analisis pushover. 


\section{Analisis gempa metode direct displacement based design}

1. Perpindahan Tingkat

Nilai perpindahan rencana dipengaruhi oleh faktor drift limit $(\theta)$, yaitu sebesar 0,02 untuk tingkat kinerja life safety, dan mode shape dari struktur. Mode shape masing-masing tingkat dihitung dengan menggunakan rumus:

$$
\delta_{i}=\frac{4}{3}\left(\frac{H_{i}}{H_{n}}\right)\left(1-\frac{H_{i}}{4 H_{n}}\right)
$$

dengan $\delta_{i}=$ mode shape tingkat ke- $i, H_{i}=$ tinggi struktur hingga tingkat ke- $i$, dan $H_{n}=$ tinggi total struktur.

Desain perpindahan tingkat untuk lantai pertama dihitung dengan rumus:

$$
\Delta_{1}=\theta \times H_{1}
$$

dengan $\Delta_{l}=$ perpindahan tingkat pertama, dan $\theta=$ batas drift sesuai dengan tingkat kinerja yang ditentukan. Dan untuk lantai berikutnya dengan rumus:

$$
\Delta_{i}=\delta_{i} \times \frac{\Delta_{1}}{\delta_{1}}
$$

dengan $\Delta_{i}=$ perpindahan rencana pada tingkat ke- $i$.

Hasil perhitungan perpindahan rencana dapat dilihat pada Tabel 4.

Tabel 4. Perhitungan Perpindahan Rencana

\begin{tabular}{ccccccccc}
\hline Tingkat & $\begin{array}{c}H_{i} \\
(\mathrm{~m})\end{array}$ & $\begin{array}{c}m_{i} \\
(\text { ton})\end{array}$ & $\delta_{i}$ & $\omega_{\theta}$ & $\begin{array}{c}\Delta_{i} \\
(\mathrm{~m})\end{array}$ & $\begin{array}{c}m_{i} \cdot \Delta_{i} \\
\text { (tonm) }\end{array}$ & $\begin{array}{c}m_{i} \cdot \Delta_{i}^{2} \\
\left.\text { (tonm }{ }^{2}\right)\end{array}$ & $\begin{array}{c}m_{i} \cdot \Delta_{i} \cdot H_{i} \\
(\text { tonm }\end{array}$ \\
\hline 15 & 71,7 & 152,99 & 1 & 0,9062 & 0,9902 & 151,49 & 150,00 & 10861,61 \\
\hline 14 & 66,9 & 201,54 & 0,9539 & 0,9062 & 0,9445 & 190,35 & 179,79 & 12734,68 \\
\hline 13 & 62,1 & 201,54 & 0,9048 & 0,9062 & 0,8959 & 180,55 & 161,75 & 11212,36 \\
\hline 12 & 57,3 & 201,54 & 0,8527 & 0,9062 & 0,8443 & 170,16 & 143,66 & 9749,96 \\
\hline 11 & 52,5 & 201,54 & 0,7976 & 0,9062 & 0,7897 & 159,16 & 125,70 & 8356,06 \\
\hline 10 & 47,7 & 201,54 & 0,7395 & 0,9062 & 0,7322 & 147,57 & 108,06 & 7039,26 \\
\hline 9 & 42,9 & 201,54 & 0,6784 & 0,9062 & 0,6718 & 135,39 & 90,95 & 5808,14 \\
\hline 8 & 38,1 & 201,54 & 0,6144 & 0,9062 & 0,6084 & 122,61 & 74,59 & 4671,29 \\
\hline 7 & 33,3 & 201,54 & 0,5473 & 0,9062 & 0,5420 & 109,23 & 59,20 & 3637,28 \\
\hline 6 & 28,5 & 201,54 & 0,4773 & 0,9062 & 0,4726 & 95,25 & 45,02 & 2714,72 \\
\hline 5 & 23,7 & 204,57 & 0,4043 & 0,9062 & 0,4003 & 81,90 & 32,79 & 1940,94 \\
\hline 4 & 18,9 & 208,26 & 0,3283 & 0,9062 & 0,3251 & 67,70 & 22,01 & 1279,57 \\
\hline 3 & 14,1 & 208,26 & 0,2493 & 0,9062 & 0,2469 & 51,41 & 12,69 & 724,92 \\
\hline 2 & 9,3 & 208,26 & 0,1673 & 0,9062 & 0,1657 & 34,51 & 5,72 & 320,92 \\
\hline 1 & 4,5 & 207,16 & 0,0824 & 0,9062 & 0,0900 & 18,64 & 1,68 & 83,90 \\
\hline 0 & 0 & 16,50 & 0 & 0,9062 & 0,0000 & 0 & 0 & 0 \\
\hline Jumlah & & 3019,87 & & & & 1715,9 & 1213,60 & 81135,61 \\
\hline
\end{tabular}

2. Perpindahan $S D O F$

Desain perpindahan dari sistem SDOF (Single Degree of Freedom) untuk arah X dan Y adalah sebesar 0,7073 m yang diperoleh dari rumus berikut.

$$
\Delta_{d}=\frac{\sum_{i=1}^{n}\left(m_{i} \Delta_{i}^{2}\right)}{\sum_{i=1}^{n}\left(m_{i} \Delta_{i}\right)}
$$

dengan $m_{i}=$ massa tingkat- $i$, dan $\Delta_{i}=$ perpindahan pada tingkat ke- $i$.

3. Massa Efektif

Massa efektif dari sistem SDOF adalah sebesar 2426,1784 ton yang diperoleh dari rumus berikut.

$$
m_{e}=\frac{\sum_{i=1}^{n}\left(m_{i} \Delta_{i}\right)}{\Delta_{d}}
$$

dengan $m_{i}=$ massa tingkat $i, \Delta_{i}=$ perpindahan pada tingkat ke- $i$ dan $\Delta_{d}=$ perpindahan rencana $S D O F$. 
4. Tinggi Efektif

Tinggi efektif struktur dalam sistem SDOF yang setara dengan struktur $M D O F$ adalah sebesar 47,2839 m yang diperoleh dari rumus berikut.

$$
H_{e}=\frac{\sum_{i=1}^{n}\left(m_{i} \Delta_{i} h_{i}\right)}{\sum_{i=1}^{n}\left(m_{i} \Delta_{i}\right)}
$$

dengan $m_{i}=$ massa tingkat $-i, \Delta_{i}=$ perpindahan pada tingkat ke- $i$, dan $h_{i}=$ tinggi struktur hingga tingkat ke- $i$.

5. Daktilitas Perpindahan

Daktilitas perpindahan untuk model sistem SDOF adalah sebesar 1,6892 yang diperoleh dari rumus berikut.

$$
\mu=\frac{\Delta_{d}}{\Delta_{y}}
$$

dengan $\Delta_{y}=$ perpindahan leleh sebesar $\theta_{\mathrm{y}} \times H_{e}, \theta_{\mathrm{y}}=$ sudut leleh sebesar $0,5 \frac{L_{b}}{h_{b}}$ untuk rangka beton, $\varepsilon_{y}=\frac{f_{y e}}{E}$ dan $f_{y e}=1,1 \times f_{y}$.

6. Redaman Viscous Ekuivalen

Redaman viscous ekuivalen untuk sistem SDOF ini adalah sebesar 12,3376\% yang diperoleh dari rumus berikut.

$$
\xi_{e q}=0,05+0,577\left(\frac{\mu-1}{\mu \pi}\right)
$$

dengan $\mu=$ daktilitas perpindahan sistem $S D O F$.

7. Periode Efektif

Periode efektif sistem SDOF diperoleh dengan mengubah respons spektrum elastis pada redaman 5\% menjadi spektra perpindahan pada redaman viscous ekuivalen sistem SDOF, yaitu sebesar 12,3376\%. Kemudian berdasarkan dengan perpindahan rencana, $\Delta_{d}$, diperoleh periode sebesar 7,3 detik seperti pada Gambar 8.

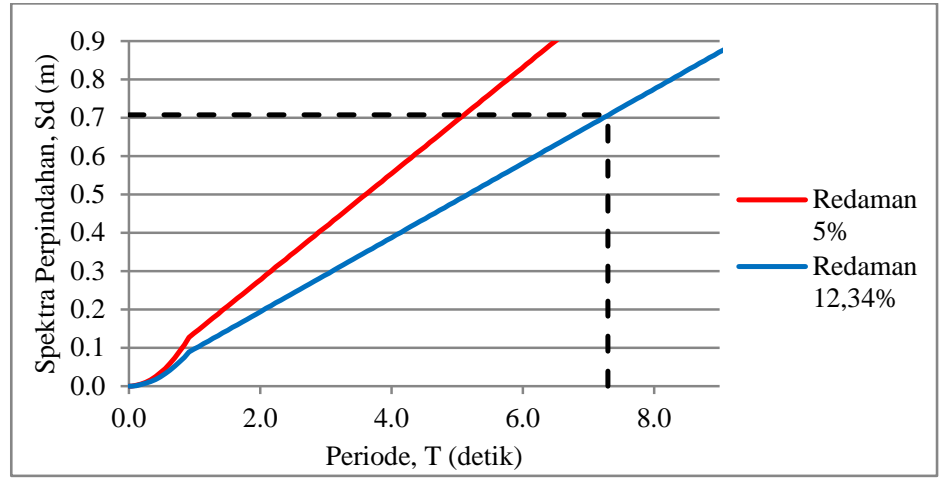

Gambar 8. Spectral Displacement untuk Redaman 11,5224\%

8. Kekakuan Efektif

Nilai kekakuan efektif untuk sistem SDOF adalah sebesar 17973,6696 kN/m yang diperoleh berdasarkan rumus berikut.

$$
K_{e}=\frac{4 \pi^{2} m_{e}}{T_{e}^{2}}
$$

dengan $m_{e}=$ massa efektif dan $T e=$ periode efektif.

9. Gaya Geser Dasar

Gaya geser dasar yang diperoleh berdasarkan metode Direct Displacement Based Design ini adalah sebesar $12711,9559 \mathrm{kN}$ untuk kedua arah yang diperoleh berdasarkan rumus berikut.

$$
V_{\text {base }}=K_{e} \times \Delta_{d}
$$

dengan $K e=$ kekakuan efektif dan $\Delta_{d}=$ perpindahan rencana. 
Tabel 5. Perbandingan Gaya Geser Dasar

\begin{tabular}{cccc}
\hline $\begin{array}{c}\text { Gaya Geser } \\
\text { Dasar }\end{array}$ & $\begin{array}{c}\text { Metode Gaya } \\
\text { Lateral Ekuivalen }\end{array}$ & $\begin{array}{c}\text { Metode Respons } \\
\text { Spektrum Ragam }\end{array}$ & $\begin{array}{c}\text { Metode Direct } \\
\text { Displacement } \\
\text { Based Design }\end{array}$ \\
\hline Arah X & $9736,6441 \mathrm{kN}$ & $7997,3626 \mathrm{kN}$ & $12711,9559 \mathrm{kN}$ \\
\hline Arah Y & $9741,1497 \mathrm{kN}$ & $7997,7588 \mathrm{kN}$ & $12711,9559 \mathrm{kN}$ \\
\hline
\end{tabular}

\section{Analisis pushover}

Hasil analisis pushover adalah berupa kurva kapasitas dari struktur yang selanjutnya digunakan untuk mengevaluasi kinerja struktur. Kinerja struktur dicari dengan menggunakan 2 metode, yaitu metode spektrum kapasitas dan metode koefisien perpindahan yang diatur dalam ATC-40, FEMA 356, dan FEMA 440. Kurva kapasitas hasil analisis pushover untuk masing-masing arah dapat dilihat pada Gambar 8.
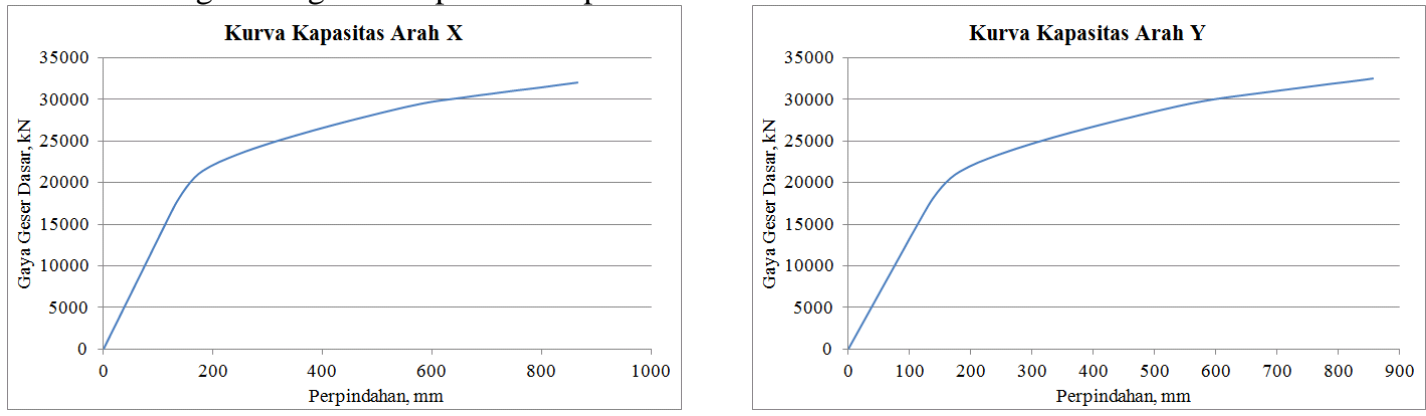

Gambar 9. Kurva Kapasitas Arah X dan Arah Y

\section{Evaluasi kinerja struktur}

Evaluasi kinerja struktur digunakan untuk mengetahui tingkat kinerja struktur yang sudah didesain. Didapatkan 4 nilai kinerja struktur dengan menggunakan 2 metode berdasarkan 3 peraturan yang umum digunakan yaitu ATC-40, FEMA 356, dan FEMA 440. Hasil nilai target perpindahan dan nilai drift dari masing-masing metode dan peraturan dapat dilihat pada Tabel 4.

Tabel 6. Target Perpindahan dan Level Kinerja Struktur

\begin{tabular}{|c|c|c|c|c|c|}
\hline \multirow{2}{*}{ Arah } & \multirow{2}{*}{ Parameter } & \multicolumn{2}{|c|}{ Metode Spektrum Kapasitas } & \multicolumn{2}{|c|}{ Metode Koefisien Perpindahan } \\
\hline & & ATC-40 & FEMA 440 & FEMA 356 & FEMA 440 \\
\hline \multirow{3}{*}{$X$} & $\Delta_{\text {roof }}(\mathrm{mm})$ & 242,6109 & 623,0590 & 585,0469 & 589,4765 \\
\hline & Drift aktual (m) & 0,00338 & 0,00869 & 0,00816 & 0,00822 \\
\hline & Level Kinerja & $\begin{array}{l}\text { Immediate } \\
\text { Occupancy }\end{array}$ & $\begin{array}{l}\text { Immediate } \\
\text { Occupancy }\end{array}$ & $\begin{array}{l}\text { Immediate } \\
\text { Occupancy }\end{array}$ & $\begin{array}{l}\text { Immediate } \\
\text { Occupancy }\end{array}$ \\
\hline \multirow{3}{*}{$\mathrm{Y}$} & $\Delta_{\text {roof }}(\mathrm{mm})$ & 245,2941 & 628,5710 & 590,6614 & 595,1473 \\
\hline & Drift aktual (m) & 0,00342 & 0,00877 & 0,00824 & 0,00830 \\
\hline & Level Kinerja & $\begin{array}{l}\text { Immediate } \\
\text { Occupancy }\end{array}$ & $\begin{array}{l}\text { Immediate } \\
\text { Occupancy }\end{array}$ & $\begin{array}{l}\text { Immediate } \\
\text { Occupancy }\end{array}$ & $\begin{array}{l}\text { Immediate } \\
\text { Occupancy }\end{array}$ \\
\hline
\end{tabular}

\section{KESIMPULAN DAN SARAN}

\section{Kesimpulan}

Berdasarkan hasil analisis yang telah dilakukan, dapat disimpulkan beberapa hal yaitu:

1. Gaya geser dasar dengan analisis Direct Displacement Based Design untuk struktur dengan sistem rangka beton pemikul momen khusus dalam penelitian ini lebih besar dibandingkan dengan gaya geser dasar yang didesain berdasarkan SNI 1726:2012. Hal ini menggambarkan bahwa perencanaan dengan Direct Displacement Based Design menghasilkan desain yang lebih aman daripada perencanaan dengan SNI 1726:2012, namun lebih boros.

2. Kinerja struktur bangunan yang didesain berdasarkan SNI 1726:2012 ini memenuhi syarat kinerja minimum, yaitu life safety. Berdasarkan metode spektrum kapasitas dan metode koefisien perpindahan berdasarkan ATC40, FEMA 356 dan FEMA 440 diperoleh tingkat kinerja Immediate Occupancy. 
3. Tingkat kinerja yang diperoleh berdasarkan metode spektrum kapasitas menurut ATC-40 belum tentu aman jika dibandingkan dengan peraturan FEMA karena drift yang diperoleh berdasarkan ATC-40 jauh lebih kecil dibandingkan dengan drift yang diperoleh berdasarkan FEMA.

\section{Saran}

Berdasarkan hasil analisis yang penulis lakukan, maka saran yang dapat diberikan yaitu:

1. Perlu dilakukan lebih banyak penelitian dengan variasi model struktur yang berbeda untuk membandingkan desain gempa berbasis gaya dan berbasis perpindahan.

2. Perlu dilakukan analisis kinerja bangunan dengan lebih banyak metode agar kinerja bangunan tersebut dapat diketahui dengan jelas. Selain itu agar dapat diketahui metode mana saja yang memberikan hasil yang paling mendekati.

\section{DAFTAR PUSTAKA}

American Society of Civil Engineers. (2010). Minimum Design Loads for Buildings and Other Structures. Virginia: American Society of Civil Engineers.

American Society of Civil Engineers. (2014). Seismic Evaluation and Retrofit of Existing Buildings. Virginia: American Society of Civil Engineers.ATC-40. (1996).

Seismic Evaluation and Retrofit of Concrete Buildings Volume 1. California: Applied Technology Council.

Badan Standardisasi Nasional. (2012). Tata Cara Perencanaan Ketahanan Gempa untuk Struktur Bangunan Gedung dan Non Gedung (SNI 1726:2012). Jakarta: Badan Standardisasi Nasional.

Badan Standardisasi Nasional. (2013). Beban Minimum untuk Perancangan Bangunan Gedung dan Struktur Lain (SNI 1727:2013). Jakarta: Badan Standardisasi Nasional.

Badan Standardisasi Nasional. (2013). Persyaratan Beton Struktural untuk Bangunan Gedung (SNI 2847:2013). Jakarta: Badan Standardisasi Nasional.

FEMA 356. (2002). Prestandard and Commentary for The Seismic Rehabilitation of Buildings. Wasington, D.C.: Federal Emergency Management Agency

FEMA 440. (2005). Improvement of Nonlinear Static Seismic Analysis Procedures. Wasington, D.C.: Federal Emergency Management Agency.

Priestley, M.J.N., dkk. (2007). Displacement-Based Seismic Design of Structures. Pavia: IUSS Press.

Pusat Litbang Perumahan dan Pemukiman. (2018). Desain Spektra Indonesia. http://puskim.pu.go.id/Aplikasi/ desain_spektra_indonesia_2011/. Diakses 25 September 2018.

Tavio dan Usman Wijaya. (2018). Desain Rekayasa Gempa Berbasis Kinerja Edisi Kedua. Yogyakarta: Andi.

Wight, James K. dan James G. MacGregor. (2012). Reinforced Concrete Mechanics and Design Sixth Edition. New Jersey: Pearson Education, Inc. 